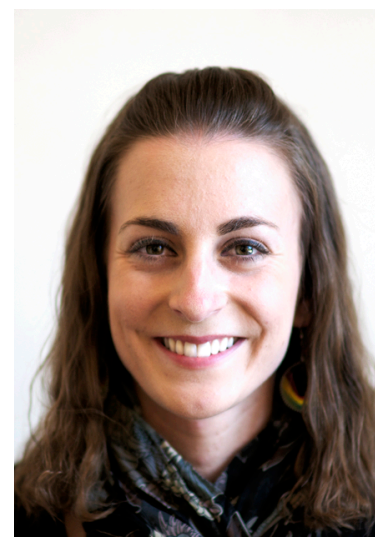

ELENA REYNOLDS is pursuing a Master of Arts in History at Cal Poly, San Luis Obispo and is a member of Cal Poly's Phi Alpha Theta chapter. She holds a Bachelor of Arts degree in History with a minor in Political Science from Bob Jones University, where she graduated cum laude. Her academic interests include Armenian and Middle Eastern history, Holocaust and genocide studies, and United States foreign policy. 


\section{A NEW ERA IN AMERICAN FOREIGN POLICY: JIMMY CARTER, HUMAN RIGHTS AND IRAN}

Elena Reynolds

It is a new world that calls for a new American foreign policy ...

We have reaffirmed America's commitment to human rights as a

fundamental tenet of our foreign policy. ${ }^{1}$

- Jimmy Carter, Address on Human Rights and Foreign Policy,

University of Notre Dame, May 22, 1977

Few presidents have expressed such passion for human rights, as has Jimmy Carter. In both his 1977 inaugural address and a commencement speech given at the University of Notre Dame later that year, Carter shared his vision for a new era in American foreign policy_one based on the democratic idealism of Woodrow Wilson, which championed freedom, peace, and human rights. ${ }^{2}$ He clung to this Wilsonian worldview, believing that "the demonstration of

${ }^{1}$ Jimmy Carter, "Human Rights and Foreign Policy" (commencement speech, Notre Dame University, South Bend, IN, May 22, 1977). The Miller Center, ttp://millercenter.org/president/ speeches/detail/3399 (accessed October 28, 2011).

${ }^{2}$ Erwin C. Hargrove, Jimmy Carter as President: Leadership and the Politics of Public Good (Baton Rouge: Louisiana State University Press, 1988), 112. Peter G. Bourne, Jimmy Carter: A Comprehensive Biography from Plains to Postpresidency (New York: Scribner, 1997), 384. 
American idealism was a practical and realistic approach to foreign affairs." Like Wilson, Carter felt that he did not have to choose between idealism and realism. As a result, he struggled to find balance between his idealist bent and the realism that confronted him as president.

Despite coming to office with little experience in foreign affairs, Carter gave careful thought to his international agenda, placing human rights at the top of his list. ${ }^{4} \mathrm{He}$ believed that America should keep its allies and adversaries accountable for their human rights records, regardless of the risks involved. To accomplish this, he set consequences for nations violating human rights, using American humanitarian aid and financial assistance as leverage to force countries into compliance with his policies. ${ }^{5} \mathrm{He}$ would use such methods in Iran. However, inexperience, political gaffes, conflicting advice from his advisors, and a series of disastrous events outside his control would ultimately undermine his ambitions, efforts, and achievements as president.

Carter is often blamed for the disintegration of U.S.-Iran relations, yet he was not the first or last president to make mistakes there. Nearly every president, from Franklin D. Roosevelt to Gerald Ford, blundered when it came to Iran, but Carter's miscalculations were perhaps the most glaring. To critically evaluate Carter's human rights policies in Iran, it is vital to look at presidential decisions made there prior to his presidency. Gaining this context makes it easier to understand the obstacles he faced coming into office. Once this is understood, the following questions can be answered: How did Carter's fundamental tenet shape his policies in Iran? Were Carter's human rights policies to blame for the Islamic Revolution and subsequent Islamization of Iran? Did Carter's human rights policies fail in Iran?

For more than a century, the United States enjoyed a healthy relationship with Iran. James Bill, historian, Iranian expert, and former State Department diplomat, states, "Few international relationships have had a more positive beginning then that which characterized Iranian-American contacts." ${ }^{\prime 6}$ Despite

${ }_{3}^{3}$ Jimmy Carter, Keeping Faith: Memoirs of a President (New York: Bantam Books, 1982), 142-143.

${ }^{4}$ Robert A. Strong, Working in the World: Jimmy Carter and the Making of American Foreign Policy (Baton Rouge: Louisiana State University Press, 2000), 261.

${ }^{5}$ Michael Ledeen and William Lewis, Debacle: The American Failure in Iran, 1st ed. (New York, Knopf, 1981), 68-69.

${ }^{6}$ James A. Bill, The Lion and the Eagle: The Tragedy of American-Iranian Relations (New Haven: Yale University Press, 1988), 4-5. 
promising beginnings, signs of tension were evident prior to World War II and continued into the postwar period. In 1925, when Reza Shah Pahlavi staged a successful coup overthrowing the Qajar dynasty, his goal was to unify his nation and stop foreign influence in its internal affairs. However, his rumored ties with Nazi Germany led to an Anglo-Soviet takeover in 1941. ${ }^{\text {This event }}$ fueled Iranian resentment toward foreign interventionism. The staged coup placed Pahlavi's oldest son, Mohammad Reza Shah Pahlavi, in control as a constitutional monarch. During World War II, United States troops stationed in Iran received extraterritorial rights, including exemption from punishment under Iranian law. Iran viewed this as an infringement of its sovereignty and vehemently objected. President Franklin D. Roosevelt ignored the problem, upholding United States civil and criminal codes. ${ }^{8}$ Things were further complicated at the Tehran Conference in 1943, when Roosevelt refused to meet with the shah. Iranians saw Roosevelt's behavior as an insult and a symbol of American arrogance and ignorance of their country. ${ }^{9}$

Despite becoming a constitutional monarch following the 1940s coup, Mohammad Reza Shah Pahlavi did not gain full control until after another coup in 1953, backed by the United States and Great Britain. This coup deposed democratically elected nationalist Prime Minister Mohammad Mossadegh. Outraged and visibly disillusioned, nationalists viewed the coup as a symbol of American imperialist designs. ${ }^{10}$ Iranians' image of America as a liberator and protector from Soviet, British, German, and French aggression was tarnished by this incident. ${ }^{11}$ To make matters worse, the shah used the coup to consolidate power, leaving his people further embittered toward the United States. According to Bill, "this direct covert operation left a running wound that bled for twenty-five years and contaminated America's relations with the Islamic Republic of Iran following the revolution of 1978-79." 12

The relationship was strained further under President Lyndon B. Johnson. Despite considerable interaction with Iran as vice president, like leaders before

${ }^{7}$ Strong, 46.

${ }^{8}$ Bill, 46-47.

${ }^{9}$ Ibid.

${ }^{10}$ Mossadegh was considered a threat to American and British oil interests. He had also been stirring up anti-American sentiments, protesting United States support for monarchical authoritarianism after the shah received, at his request, $\$ 10$ million in military aid. Bill, 50 .

${ }^{11}$ Ibid., 4-5.

${ }^{12}$ Ibid., 86. 
and after him, he overlooked how the shah's human rights violations combined with unwanted United States military occupation could become a breeding ground for resentment. ${ }^{13}$ In 1963, the shah launched his White Revolution, an attempt to modernize his country economically, structurally, and politically. Like John F. Kennedy, Johnson enthusiastically supported the program and the shah's subsequent crackdown on those protesting the changes. ${ }^{14}$ The United States would continue its support for Iran, viewing the shah as a valuable ally for his attempts at westernization, support for Israel and United States policies in the Middle East, and condemnation of Egyptian president Abdul Nasser's perceived radicalism.

During the Nixon and Ford administrations ties strengthened between the two countries. ${ }^{15}$ Both Nixon and Ford gave generous military assistance to the shah, hoping to insure regional stability. Gradually Ford would express his concern about arms sales, especially after the shah began to crack down on political dissidents. To combat these problems, Congress enacted legislation restricting the amount of American military aid and economic assistance given to countries violating human rights. ${ }^{16}$ Despite the legislation and concerns about the shah's aggressive behavior, the United States maintained its positive relationship with the shah and his political elites, while ignoring the dissatisfaction of the Iranian masses. ${ }^{17}$

When assessing Carter's relationship with Iran, it is important to examine how his fundamental tenet shaped his policies there. While Carter continued many policies established under the Nixon and Ford administrations, his Secretary of State, Cyrus Vance, noted, "there would be marked differences in the way in which we conducted our bilateral relations, particularly as regards arms sales and human rights." ${ }^{18}$ As part of his human rights agenda, Carter criticized and questioned the wisdom of selling large amounts of armaments to Iran, a newly developing country with a poor track record on human rights. Fearing the relationship could be permanently damaged, the State Department urged Carter not to speak publicly about the shah's human rights violations

\footnotetext{
${ }^{13}$ Ibid., 154.

${ }^{14}$ Ibid., 156. Strong, 46.

${ }^{15}$ Bill, 176-177.

${ }^{16}$ Cyrus Vance, Hard Choices (New York: Simon and Schuster, 1983), 314-316.

${ }^{17}$ Bill, 97.

${ }^{18}$ Vance, 314.
} 
during the first few months of his presidency. Instead, Carter let actions speak louder than words. He began with strict enforcement of his human rights policies, leaving vacant the ambassadorship to Tehran for six months. ${ }^{19}$ Carter also cancelled the sale of 250 F-16 fighter planes and suspended tear gas shipments. Carter's goal was to force the shah to change his ways in order to obtain the supplies he requested. Initially Carter's policies succeeded, as historian Donald S. Spencer notes, "for no national leader on Earth submitted with greater alacrity to U.S. human rights pressure." 20

To appease the United States, the shah took bold steps toward liberalization, making changes in Iranian law, policy, and personnel. He reorganized his cabinet and released hundreds of political prisoners. In addition, he pledged to end the torture of inmates, grant more freedom to the press and political opposition groups, and expand individual access to due process. The shah also permitted the International Red Cross to inspect prisons and assess human rights issues within the country. ${ }^{21}$ Despite improvements, the shah's reforms were simply for show. He was eager to gain approval and therefore willing to kowtow to the United States to get what he wanted.

While Carter tried to play tough, some of his advisors expressed concerns that doing so would permanently jeopardize the relationship between the two countries. As a result, the administration chose to approach human rights issues more cautiously during Secretary Vance's May 1977 trip to Tehran. While there, Vance invited the shah to the White House that November, an invitation the shah gladly accepted. This extension of friendship was one way through which Carter hoped to maintain positive relations. Vance spoke briefly to the shah about human rights, explaining that these policies were not new, but rather important American traditions that the United States pledged to uphold. The shah defended his country's human rights record and need to restrain Communists and other groups trying to undermine his leadership. He made it clear that he did not oppose United States human rights policies so long as they did not single out his country, threaten his leadership, or compromise national security. ${ }^{22}$ Following these issues, the two men discussed arms sales.

19 The hope was that the shah would be reminded of the "disdainful distance at which he would be kept by the new Carter team" as long as he oppressed his people. Donald S. Spencer, The Carter Implosion: Jimmy Carter and the Amateur Style of Diplomacy (New York: Praeger, 1988), 74.

${ }^{20}$ Ibid.

${ }^{21}$ Strong, 48-49.

${ }^{22}$ Vance, 318-319. 
Vance informed the shah that Carter would honor a promise made under the Ford Administration for a sale of 160 F-16 fighter planes. The shah had also requested highly sophisticated radar-equipped aircraft (AWACS) with state-ofthe-art electronic surveillance and communication devices, but Vance made it clear that these would only be given pending congressional approval. ${ }^{23}$

The shah had originally requested ten AWACS, but Carter reduced the number to seven in the proposal sent to Congress. Congress rejected the plan "on the grounds that the security of advanced electronic devices could not be assured in Iran." ${ }^{24}$ Although Carter intended to submit a revised proposal at a later date, the shah was infuriated by the delay or worse, the complete rejection of the sale. To express his dissatisfaction, the shah sent Carter an angry letter threatening to cancel the order. ${ }^{25}$ Carter was troubled by his predicament and recalls in his memoir that, "I was attempting to reduce the sale of offensive weapons throughout the world, but it was not possible to make excessively abrupt changes in current practices, because of contracts already in existence." ${ }^{26}$ Carter saw the decision to sell more arms as a double standard, yet he knew that the United States could not afford to lose Iranian oil or its surveillance stations along the Iran boarder, which were vital to monitoring Soviet missile activity. The United States had formed a valuable alliance, which was not worth losing for the sake of human rights. Since alienating Iran could prove disastrous, a situation Carter readily acknowledged, he was forced to part with his fundamental tenet.

In the fall of 1977, Congress finally approved the AWACS sale, but only after the insertion of safeguard provisions. The incident, which evidenced distrust of the shah's regime, was a major embarrassment to U.S.-Iran relations and tarnished Carter's image as a president committed to reducing arms sales. For Carter, the ordeal exposed his internal conflict between idealism and realism. For the shah, it raised concerns about Carter's trustworthiness.

The shah's November visit to Washington was an opportunity to ease tensions created by the AWACS debacle. During the visit, the two had time to discuss the AWACS sale. The shah told Carter that he understood the situation

\footnotetext{
${ }^{23}$ Ibid., 316.

${ }^{24}$ Gaddis Smith, Morality, Reason, and Power: American Diplomacy in the Carter Years (New York: Hill and Wong, 1986), 183-184.

${ }^{25}$ Strong, 49-50.

${ }^{26}$ Carter, 434-435.
} 
and agreed to provide a detailed list of future military needs in order to prevent a repeat of the incident. The shah's statements revealed his expectation that the United States would continue to supply the military needs of his country and it appears that Carter agreed to do so. In addition to the AWACS fiasco, the two leaders discussed oil, weapons deals, and economic issues. The shah's human rights practices were briefly addressed, but Carter did not pursue the topic. Both leaders seemed pleased that human rights had not interfered with issues like oil prices. However, the agenda proved contrary to Carter's claim that human rights were a primary foreign policy objective. Whatever progress was made during the visit, it is clear that Carter caved to political pressure and was willing to forgo his fundamental tenet in this instance and many others throughout his presidency.

Six weeks after the shah's visit, Carter traveled to Tehran on New Year's Eve. He had not planned to visit Iran during his nine-day overseas trip, but the country was a convenient stopping point on his way from Poland to India. Prior to his arrival, Carter's Deputy Secretary of State, Warren Christopher, issued a memo outlining five foreign policy issues that needed to be addressed with the shah. These included energy and oil concerns, nuclear cooperation, and Middle East stability. Human rights were placed at the bottom of the list and Christopher urged Carter only to address maintaining Iranian law and order. Human rights were yet again an afterthought.

Perhaps the most visible sign of Carter's parting with his fundamental tenet came during a speech he delivered at the shah's New Year's Eve dinner party in which he stated, "Iran under the leadership of the Shah is an island of stability in one of the more troubled areas of the world. This is a great tribute to you, Your Majesty, and to your leadership, and to the respect, and admiration and love which your people give to you." 27 While Carter's well-intentioned speech might have been customary to reiterate strong relations between the two countries, it might also have been viewed as a manifestation of his ignorance about Iranian dissatisfaction with the shah. However, earlier events showed this not to be the case. Carter admitted that he saw no visible signs of popular discontent in his short time in Iran, but acknowledged that he was aware of the brutality of Iran's secret police (SAVAK). However, he was willing to put strategic and economic concerns above human rights as evidenced in the AWACS sale. ${ }^{28} \mathrm{He}$

\footnotetext{
27 Bill, 233.

28 Carter, 437.
} 
did not want to compromise in this regard, but political pressure dictated his course. Secretary Vance once commented that, "Carter did what he thought American values and interests demanded, even though he was keenly aware of the political risks." ${ }^{29}$ But perhaps the greatest political risk was putting American needs above those of the Iranian people. In the years to come, that speech would come back to haunt him as Iran degenerated, presenting the greatest challenge his administration would face.

One week after Carter's visit, riots broke out in Iran. The island of stability was no more. By mid-1978, opposition to the shah had grown into a fullfledged Islamic revolution led by Ayatollah Khomeini, a well-known political and religious figure recently returned from exile. Carter was now faced with the difficult task of figuring out what to do. Throughout the revolution, Zbigniew Brzezinski, Carter's National Security Advisor, and Cyrus Vance fought over what actions should be taken. Brzezinski and Vance were both experienced in foreign policy, but held vastly different positions on a number of key issues. While Vance was a cautious, steady diplomat, Brzezinski was a more impatient hard-liner. As a result, they clashed over human rights and foreign policy issues on a regular basis. ${ }^{30}$

Brzezinski, saw the larger geopolitical implications of Iran's move toward an Islamic government. He realized the danger this posed not only to U.S.-Iran relations, but also to America's future in the Middle East and saw steadfast support for the shah and military force as the only way to stop the revolution. Even though he knew Carter was opposed to force, Brzezinski continued to press for it. Vance, along with several cabinet members, favored reforms and a centrist government, believing this to be the only way the shah could save himself.

At the urging of Washington, the shah attempted to suppress unrest through reforms (liberalization). He freed nearly 1,500 political prisoners and promised to hold parliamentary elections in $1979 .{ }^{31}$ He also established a centrist coalition government, which failed due to the deterioration of his power. The shah's governmental reforms had come too late to solve the country's problems.

\footnotetext{
${ }^{29}$ Spencer, 65.

${ }^{30}$ Strong, Robert A., consulting ed., "Essays on Jimmy Carter and His Administration: Foreign Affairs," The Miller Center, http://millercenter.org/president/carter/essays/biography/5 (accessed November 5, 2011).

${ }^{31}$ Spencer, 189.
} 
The shah's attempt to curb violence through military force also failed, because his soldiers no longer followed his instructions.

Throughout the ordeal, Carter's advisors were in gridlock. Brzezinski, thoroughly exacerbated by disagreements and indecision, took matters into his own hands. He used his status as chairman of the Special Coordinating Committee to undermine the State Department's ability to collect and analyze information. This allowed him to shape policy decisions while claiming that the State Department was receiving all necessary information. Brzezinski also made secret contacts with the shah through the Iranian ambassador, Ardeshir Zahedi. By this time Brzezinski felt the only thing the shah could do was exercise "unwavering and confident force" to hold his regime together. ${ }^{32} \mathrm{He}$ tried to push the shah in this direction, but after receiving conflicting advice from Brzezinski and Vance, the shah cut off his ties with Brzezinski.

Conflicts continued throughout the administration with Assistant Secretary Patricia Derian insisting that the shah implement more reforms, while Ambassador William H. Sullivan in Teheran disagreed with Brzezinski's proposal to use force, expressing his doubts that the shah "retained sufficient support to use force effectively." ${ }^{33}$ As the shah's power continued to decline, disagreements arose between Brzezinski and Vance again over whether or not the United States should move toward discussions with Ayatollah Khomeini. This infighting, which continued throughout the entire crisis, confused Carter at a time when he needed clarity most. In the end it seems that Carter's team spent more time working against each other than for their president. ${ }^{34}$

But Carter's story does not end here. After his government was overthrown, the shah was forced into exile. Eventually his declining health prompted him to request treatment in the United States. Despite reservations, the Carter administration granted him entry because he had been a long-time ally. This decision proved disastrous. As a result, the United States embassy in Tehran was seized and fifty-two hostages were taken and held for 444 days. Initially Carter deemed military options too risky, fearing the hostages might be killed. When Carter realized that he could no longer depend on diplomacy, he organized a

\footnotetext{
${ }^{32}$ Ibid.

${ }^{33}$ Ibid.

${ }^{34}$ Alexander Moens, "President Carter's Advisors and the Fall of the Shah," Political Science Quarterly 106, no. 2 (Summer 1991): 211-237.
} 
rescue operation that failed miserably. He took full responsibility for the incident, but the damage done to U.S.-Iran relations was now irreparable.

Were Carter's human rights policies to blame for the Islamic Revolution and subsequent Islamization of Iran? Carter's speech, in which he proclaimed Iran an "island of stability," certainly fueled anti-shah sentiments, but to say that his policies were responsible for the revolution and subsequent Islamization might be unfair. Historian Gaddis Smith believes that Carter's human rights policies were not to blame for the revolution. He suggests that there was little Carter could have done to prevent or suppress the violence short of military force. Smith indicates that Carter's unwillingness to do so did not derive from his human rights policies, but rather his belief that force would not save the situation. ${ }^{35}$

Others like Historian Donald S. Spencer believe Carter's "extreme" and aggressive human rights policies, which demanded immediate change, were responsible for the acceleration of the revolution and Iran's shift toward a fourteenth-century theocracy. He argues that Carter's human rights agenda demanded the impossible and pressed too hard for "complete and immediate capitulation by the Shah to their own perception of what Iran should become." 36 Spencer observes that Carter's human rights policies failed because he urged the shah to westernize his country, in spite of strong opposition by the Iranian people. He also condemns Carter for censuring the government for failing to make drastic changes quickly enough and then abandoning the shah, who continued to follow previously given instructions from Washington. In doing this, Spencer argues that Carter successfully subverted a major strategic and political ally. ${ }^{37}$

Perhaps the most important question to ask when assessing Carter's presidency is whether his human rights policies failed in Iran. Historian Frank Ninkovich views Carter's human rights policies as unsuccessful due to his refusal to relinquish support for the shah. Ninkovich portrays Carter as afraid of failure, which derived from his strong Wilsonian ideals. He argues that Carter could not get past his crusade for human rights and deal with real world problems outside of that context. In an attempt to avoid catastrophe, he brought it upon himself.

\footnotetext{
${ }^{35}$ Smith, 244.

${ }^{36}$ Spencer, 65-66.

${ }^{37}$ Ibid., 66.
} 
Ninkovich believes that had Carter severed ties with the shah and recognized Khomeini, the United States may have saved its relationship with Iran. ${ }^{38}$

Like Ninkovich, Gary Sick, a member of the National Security Council during the Iran hostage crisis, acknowledges that Carter was "instinctively a peacemaker and reformer," which left him uncomfortable with using military force ${ }^{39}$ However, he does believe that, "The assertion that the shah was paralyzed into inaction by the human rights policies of the Carter administration simply is not supported by the evidence or the shah's own testimony in dozens of conversations during the crisis." ${ }^{\prime 0}$ Sick adds that like Carter, the shah could not decide whether to launch radical reforms or a bloodbath due to "self-interest and internal political realities, not on fear of offending Washington." ${ }^{41}$ Sick suggests that Carter's human rights policies in Iran were not a failure, but due rather to the indecision on both sides, which prevented a viable solution from being reached.

Like Ninkovich and Sick, historian James Bill asserts that, "The central contradiction in America's general goals in Iran was that the United States had both real political and economic interests as well as a genuine commitment to democratic principles." ${ }^{42}$ Bill believes that Carter's human rights policies failed because he wanted the best of both worlds, which was impossible given the complex nature of international relations.

Overall, Carter's human rights record was inconsistent. Initially both he and his advisors denounced human rights violations in the Soviet Union, Iran, South Korea, Chile, El Salvador, Nicaragua, Uganda, and numerous other countries. While they suspended military and economic aid to South American and African countries, they refused to do so permanently in Iran. Fearful of losing a valuable alliance, Carter also ceased criticism of the shah's human rights record. He also shied away from denouncing the Soviet Union's policies after Leonid Brezhnev threatened to halt arms control negotiations. ${ }^{43}$

\footnotetext{
${ }^{38}$ Frank Ninkovich, The Wilsonian Century: U.S. Foreign Policy since 1900 (Chicago: IL, 1999), 251-252.

${ }^{39}$ Gary Sick, All Fall Down: America's Tragic Encounter with Iran (New York: Random House, 1985), 173.

${ }^{40}$ Ibid., 169.

41 Ibid.

42 Bill, 49.

43 Strong, "Essays on Jimmy Carter and His Administration: Foreign Affairs."
} 
In addition, he turned a blind eye to human rights violations in China and the Philippines and did nothing to prevent Pol Pot's regime in Cambodia from carrying out genocide. ${ }^{44}$

Even though his human rights policies may have been plagued by contradictions, it is important to note that Carter did enjoy some diplomatic successes, such as mediating a historic peace agreement, known as the Camp David Accords (1978), between Israel's Menachem Begin and Egypt's Anwar Sadat. This tremendous achievement "revived a long-dormant practice of presidential peacemaking, something every succeeding chief executive has emulated to varying degrees. ${ }^{\prime 5}$ Many historians applaud Carter's attempts at diplomacy throughout the world, and even in Iran, but acknowledge that his failure was giving in to the shah's requests for arms, rather than standing firm on his commitment to human rights.

Jimmy Carter, more than any other president, incorporated human rights into his foreign policies. Despite unexpected struggles and setbacks, he constantly reminded Americans that they could not remain indifferent to the fate of freedom elsewhere. In doing so, he improved the global image of the United States, lent international credibility to human rights issues, and helped set the tone for world politics in the following decades. ${ }^{46}$ Carter's vision for a new era in American foreign policy was certainly commendable, but perhaps America was not yet ready to take the step.

\footnotetext{
${ }^{44}$ George C. Herring, From Colony to Superpower: U.S. Foreign Relations Since 1776 (Oxford University Press: New York, 2008), 846-847.

${ }^{45}$ Strong, "Essays on Jimmy Carter and His Administration: Foreign Affairs."

${ }^{46}$ David F. Schmitz and Vanessa Walker, "Jimmy Carter and the Foreign Policy of Human Rights: The Development of a Post Cold War Foreign Policy," Diplomatic History, 28 (January 2004), 119.
} 
Bill, James A. The Eagle and the Lion: The Tragedy of American-Iranian Relations. New Haven: Yale University Press, 1988.

Bourne, Peter G. Jimmy Carter: A Comprehensive Biography from Plains to Postpresidency. New York: Scribner, 1997.

Carter, Jimmy. Keeping Faith: Memoirs of a President. Fayetteville: University of Arkansas Press, 1995.

"Human Rights and Foreign Policy." Commencement speech, Notre Dame University, South Bend, IN, May 22, 1977. The Miller Center. http://millercenter.org/ president/speeches/detail/3399 (accessed October 28, 2011).

Hargrove, Erwin C. Jimmy Carter as President: Leadership and the Politics of Public Good. Baton Rouge: Louisiana State University Press, 1988.

Herring, George C. From Colony to Superpower: U.S. Foreign Relations Since 1776. New York: Oxford University Press, 2008.

Ledeen, Michael and William Lewis. Debacle: The American Failure in Iran. 1st ed. New York: Knopf, 1981.

Moens, Alexander. "President Carter's Advisers and the Fall of the Shah." Political Science Quarterly 106, no. 2 (Summer 1991): 211-237.

Ninkovich, Frank. The Wilsonian Century: U.S. Foreign Policy since 1900. Chicago: IL, 1999.

Schmitz David F. and Vanessa Walker. "Jimmy Carter and the Foreign Policy of Human Rights: The Development of a Post Cold War Foreign Policy." Diplomatic History 28 (January 2004), 119.

Sick, Gary. All Fall Down: America's Tragic Encounter with Iran. New York: Random House, 1985.

Smith, Gaddis. Morality, Reason and Power: American Diplomacy in the Carter Years. New York: Hill and Wang, 1986. 
Spencer, Donald S. The Carter Implosion: Jimmy Carter and the Amateur Style of Diplomacy. New York: Praeger, 1988.

Strong, Robert A. Working in the World: Jimmy Carter and the Making of American Foreign Policy. Baton Rouge: Louisiana State University Press, 2000.

_. "Essays on Jimmy Carter and His Administration: Foreign Affairs." The Miller Center. http://millercenter.org/president/carter/essays/biography/5 (accessed November 5, 2011).

Vance, Cyrus. Hard Choices. New York: Simon and Schuster, 1983. 